УДК 159.9:37.013

DOI:

Оксана Микитюк, доктор педагогічних наук, доцент кафедри технології біологічно активних сполук, фармації та біотехнологї

Національного університету "Львівська політехніка"

Андрій Зачепа, доктор філософських наук, професор, завідувач кафедри суспільногуманітарних наук Української академії друкарства Андрій Микитюк, аспірант Вармінсько-Мазурського університету, Польща

\title{
ДОСЛІДЖЕННЯ АСПЕКТІВ ЕМОЦЙНОГО ВИГОРАННЯ У ВЧИТЕЛІВ СИСТЕМИ ПІСЛЯДИПЛОМНОЇ ПЕДАГОГІЧНОЇ ОСВІТИ
}

Стаття присвячена проблемам психічного здоров'я учителів системи післядипломної педагогічноі освіти. Авторами висвітлено результати емпіричного дослідження стану емоційного вигорання у вчителів системи післядипломної педагогічної освіти у контексті дослідження психічного здоров'я. Дослідження проводились з використанням трьох методик з групами вчителів, які проходили курсову підготовку у системі післядипломної педагогічної освіти. Окреслено шляхи запобігання емоційному вигоранню у педагогів (як превентивно-профілактичні, так і психокорекційні) з використанням треніногових занять, інтерактивних технологій, інших технологій формування елементів сприятливого екосередовища.

Ключові слова: психічне здоров'я; синдром емоційного вигорання; вчителі системи післядипломної педагогічної освіти; сприятливе екосередовище.

Лim. 13.

Oksana Mykytyuk, Doctor of Sciences (Pedagogy), Associate Professor of the Technology of Biologically Active Substances, Pharmacy and Biotechnology Department, Lviv Polytechnic National University

Andriy Zachepa, Doctor of Sciences (Philosophy), Professor,

Head of the Social and Humanitarian Sciences Department, Ukrainian Academy of Printing Andriy Mykytyuk, Postgraduate Student, University of Warmia and Mazury in Olsztyn, Poland

\section{RESEARCH OF ASPECTS OF EMOTIONAL BURNOUT OF TEACHERS OF POSTGRADUATE PEDAGOGICAL EDUCATIONAL SYSTEM}

This article is devoted to the problems of mental health of teachers working in the system of postgraduate pedagogical education. In the article, authors highlighted the results of the empirical study about the state of emotional burnout syndrome in teachers of the postgraduate pedagogical education system in the context of the study of mental health. This research was conducted by using three methodologies with groups of teachers who were trained in the system of postgraduate pedagogical education. There are ways of preventing emotional burnout in teachers (such as prophylactic-preventive, and psycho-corrective) with the use of training sessions, interactive technologies, and other technologies of the elements of a favorable eco-environment.

The burnout syndrome among teachers is actually a process of orientation of a personality in the intraindividual space, which contains psycho-constitutional features and a subjective-personal attitude to one's professional activity, which manifests itself in violation of self-identification of a personality (the emergence of cognitive dissonance). The central paradigm for the formation of a psychologically stable personality, with the prevention of the burnout syndrome among teachers, is the formation of a competency-based approach to the behaviour in the intra-individual space, with the formation of cognitive consonance and the ability to change, mastering and developing one's personality and professional competency in the educational space.

Keywords: mental health; emotional burnout syndrome; teachers of postgraduate pedagogical education system; favorable ecological environment.

П остановка проблеми. Сучасна післядипломна педагогічна освіта в Україні передбачає високі вимоги до особистісних і професійних якостей вчителя. У роботі вчителя є багато різноманітних ситуацій, пов'язаних $з$ переживанням стресу і високою емоційною напругою. Стресові фактори, переживання стресу, дія стрес-факторів це складні феномени, що проявляються у психічних і фізіологічних реакціях організму вчителя.

На протязі останніх років все більше психологів і психіатрів ведуть мову не про професійний стрес у вчителів, а про наявність синдрому емоційного вигорання вчителя. Цей синдром розвивається на фоні постійного професійного стресу. Синдром емоційного 


\section{ДОСЛІДЖЕННЯ АСПЕКТІВЕМОЦЙНОГО ВИГОРАННЯ У ВЧИТЕЛІВСИСТЕМИПСЛЯДИПЛОМНОӤПЕДАГОГІЧНОЇОСВІТИ}

вигорання у вчителів пов'язаний в першу чергу 3 постійними емоційними перевантаженнями, 3 постійним міжособистісним спілкуванням, 3 певними проявами когнітивного дисонансу. Актуальність проблеми дослідження професійного вигорання у вчителя на теперішній час можна пояснити зрослими вимогами до вчителя (Закон України "Про освіту", вимогами Державного стандарту початкової загальної середньої освіти, Державного стандарту повної загальної середньої освіти, іншими законами), зрослими вимогами до його особистісних професійних якостей, а також необхідністю пошуку шляхів корекції і запобігання емоційного вигорання і протидії стрес-факторам.

Мета статті. Мету, яку ставили перед собою автори - дослідження аспектів, аналіз і інтерпретація дослідження щодо емоційного вигорання у вчителів системи післядипломної педагогічної освіти.

Аналіз актуальних досліджень. Теоретичні і емпіричні дослідження синдрому емоційного вигорання досліджувала велика кількість науковців, зокрема (M. Anderson, E. Iwanicki, D. CroninStubbs, C. Rooks, M. Davis-Sacks, M. Leiter, T. Marek, C. Maslach, S. Jackson, A. Pines, W. Schaufeli, J. Winnubst та інш.). Велика кількість досліджень були проведені також М. Аминовим, В. Бойко, А. Марковою, Л. Митиною, О. Рукавішніковим, Т. Форманюком [4].

Педагогічна діяльність є стресогенною i потребує значних резервів самовладання та саморегуляції. У результаті величезного емоційного напруження, що виникає у педагога у процесі здійснення ним професійної діяльності, поступово знижуються когнітивно-психічні параметри і відповідно зменшується працездатність. Якщо розглядати професійне вигорання з опиранням на концепцію стресу (за Г. Селье), то відповідно напрошується висновок, що професійне вигорання - це дистрес, 3 завершенням адаптаційного синдрому після стресу - наявності стадії виснаження, що характеризується помітним зниженням енергетичного тонусу організму і емоційною лабільністю. Ряд науковців [1 - 7] дотримуються думки, що прояви емоційного захисту у формі вигорання є невід'ємним атрибутом емоційного захисту особистості. Науковець О. Рукавішніков підкреслює, що синдром емоційного вигорання характеризується стійким психічним виснаженням, розвитком дисфункціональних професійних установок і зниженням професійної мотивації [9]. Науковець В. Бойко підкреслює, що феномен “емоційне вигорання" $\epsilon$ по суті механізм психологічного захисту у формі повного або часткового зникнення емоцій у відповідь на стресові і психотравмуючі впливи. Вигорання, на думку автора, - це набутий стереотип емоційної, найчастіше професійної, поведінки, зокрема функціональний стереотип, що дозволяє особистості дозувати та економно витрачати енергетичні ресурси [3]. На думку Д. Грінберга, професійне вигорання характеризується несприятливою реакцією особистості на стрес, який вона отримала у процесі здійснення професійної діяльності, що містить поведінкові та психофізіологічні компоненти [4].

Фактори риску розвитку емоційного вигорання за Л. Новіковою є наступними: 1)соціальнопсихологічні фактори розвитку вигорання переживання несправедливості, соціальна незахищеність, відсутність підтримки, відчуття невдоволеності роботою, оплатою праці, вікові проблеми, відсутність просування по кар'єрних східцях; 2) особистісні фактори розвитку вигорання - накладання екстернального i інтернального локусу контролю; 3) професійні фактори розвитку вигорання: - працеголізм, непомірно високі вимоги до себе як професіонала і т.п. [5].

Т. Форманюк виокремлює наступні фактори емоційного вигорання [8]: особистісний фактор дія надлишку емпатійності, здатності ідеалізувати обставини, інтравертність, зайва фанатичність, емоційна холодність, здатність до інтенсивного переживання негативних обставин професійної діяльності. При рольовому факторі відіграють роль і мають опосередкований вплив також відсутність інтеграційної взаємодії, наявна недоброчесна конкуренція і т.п. Організаційний фактор характеризує відсутність емоційної і соціальної підтримки з боку колег і керівництва, надзвичайно високе професійне навантаження, неможливість впливати на прийняття рішень, необхідність прояву емоцій, що не відповідають реальному стану особи, і т.п. [9]. Аналіз літературних джерел дозволяє нам констатувати той факт, що переважаюча більшість авторів під терміном “синдром емоційного вигорання” розуміють професійний феномен, що складається 3 комплексу деструктивних симптомів і містить три компоненти: емоційне виснаження, деперсоналізацію і редукцію професійних досягнень [3-4; $11-13]$.

Детальний аналіз літературних джерел свідчить також і про те, що як і вітчизняній, так і зарубіжній психології відсутня єдина думка відносно причин, що обумовлюють виникнення емоційного вигорання. За даними ряду авторів (Т. Форманюк, 1994; K. Kondo, 1991; C. Maslach, 
1982; A. Pines, 1981 та ін.) синдром розвивається під дією трьох змінних: організаційних, особистісних, рольових. Хоча така класифікація штучно розділює організаційні і рольові фактори, що відносяться до соціальних, оскільки рольовий фактор характеристики вчителя (особистості) може бути тільки у школі, колективі, соціумі.

Виклад основного матеріалу. 3 метою отримання експериментальних даних нами були використані опитувальники методик визначення вираженості кризогенних чинників і подолання професійних криз вчителя (за О. Чоросовою), авторським опитувальником щодо емоційного здоров'я (шкалювання емоційного виснаження, деперсоналізації і редукції професійних досягнень), анкета “Здоров'я вчителя (рівень тривожності). Дослідження проводились у період 2015 - 2016 року у КЗ ЛОР “Львівський обласний інститут післядипломної педагогічної освіти” з вчителями системи післядипломної педагогічної освіти. Кількість вчителів - 298.

Порівняння досліджень емпіричної вибірки (сумарно після проведення опитування i анкетування) дозволили нам зробити наступні висновки. Анкетування і опитування груп вчителів, які включали вчителів різних категорій i спеціальностей (учителів основ медичних знань і учителів трудового навчання (технологій) показали, що у більшої частини вчителів наявні симптоми емоційного вигорання. Зокрема, \% респондентів (вчителів основ медичних знань) що підтвердили наявність симптомів емоційного вигорання становив - 65\%, вчителів трудового навчання (технологій) становив відповідно - $60 \%$. Вчителі констатували велике “психоемоційне виснаження”, що проявляється в емоційних переживаннях, підвищеним психічним виснаженням, втратою інтересу і позитивних відчуттів до оточуючих, зокрема до учнів, відчугтя “пересиченості роботою”, незадоволенням собою, оточуючими. “Деперсоналізація" проявляється (за даними анкетування) як “емоційною глухотою” і “емоційним відстороненням”, формальним виконанням професійних обов'язків, відсутності “особистої включеності і співпереживання”, а в окремих випадках, підвищеною роздратованістю і підвищеним негативізмом до оточуючих. На поведінковому рівні зростають прояви звинувачень колег у непрофесіоналізмі, відстороненості від шкільних подій. Що торкається професійної редукції, то у вчителів вона відображає ступінь вдоволеності собою як особистістю і своїм професіоналізмом. У проведеному анкетуванні вчителі констатували зниження професійної мотивації, наростання почуття негативізму по відношенню до своїх посадових обов'язків, бажання зняти з себе відповідальність, бажання ізолюватись від оточуючих, намагання уникнути виконання своїх обов'язків, висували припущення у своїх хворобах, поганому самопочутті.

Зібраний емпіричний матеріал проведених трьох анкетувань дозволив окреслити фактори, що призводять до емоційного вигорання (у всіх вчителів сумарно) - обмеження професійних очікувань у відношенні до особистісних досягнень учнів - 67\%; суб'єкт-суб'єктна взаємодія, обумовлена постійною емоційною напругою 74\%; настійна потреба професійного самовдосконалення - 52\%; непрогнозованість сучасних учнів і непередбачуваність виникнення педагогічних ситуацій $-62 \%$; низький рівень соціальної адаптації - підвищена тривожність, невпевненість усобі, емоційна нестійкість, низький рівень самооцінки тощо - 56\%; відсутність часу на вирішення родинних справ $-60 \%$; матеріальні труднощі, відсутність можливості подорожувати $-42 \%$.

Щодо пошуку шляхів запобігання емоційному вигорання у педагогів, то вони можуть бути як превентивно-профілактичні, так і психокорекційні. У процесі превентивної роботи щодо попередження професійного вигорання доцільними можуть бути дії щодо коригування власного стилю реагування на стресову ситуацію, зміну поведінкового репертуару, відпрацювання навичок конструктивної взаємодії, використання релаксаційних технік зняття напруги тощо.

Найбільш ефективною формою профілактики емоційного вигорання можна вважати тренінгові заняття, використання елементів сприятливого екосередовища, що складається 3 лікарських рослин.

Сприятливим екосередовищем ми вважаємо екосередовище реалізації соціоекологічних особистісних ставлень і ціннісних орієнтацій, що компонується 3 лікарських рослин у класі, пришкільній навчально-дослідній ділянці, пришкільному просторі [10].У межах профілактики і запобігання емоційного вигорання тренінг виступає як запланований процес модифікації зміни ставлення, знання чи поведінкових навичок педагогів у стресовій ситуації через набуття навчального досвіду 3 метою досягнення ефективної суб'єкт-суб' єктної взаємодії та подальшого успішного здійснення професійної діяльності. Доцільно використовувати для вчителів індивідуальні і групові тренінги (“Море друзів”, “Абетка спілкування”, 


\section{ДОСЛДЖЕННЯ АСПЕКТІВЕМОЦЙНОГО ВИГОРАННЯ У ВЧИТЕЛІВСИСТЕМИ ПІСЛЯДИПЛОМНОӤПЕДАГОГПНОӤ ОСВІТИ}

інтерактивні вправи, зокрема коллективно-групові, кооперативні, ситуативного моделювання, діалогового прийняття рішень), у ході яких відпрацовуються навички самодіагностики ознак професійного стресута конструктивні шляхи його подолання (формування адаптивних копінгстратегій). У процесі тренінгів можливе використання елементів казкотерапії, символдрами, музичної терапії у сприятливому екосередовищі та метафорично-асоціативних карт.

Доцільно використовувати також метод асоціювання, який запропонований А. Акиндиновою [1] (використовування вправ, що допомагають подолати дисоційовані стани шляхом занурення у стан асоціаціі). Науковець Л. Митина [11], зокрема наголошує, що для осіб з емоційним вигоранням доцільно організація груп психодрами 3 використанням рольової гри та елементів імпровізації різних життєвих ситуацій, призначених для більш повного розкриття внутрішнього світу особистості.

Висновок. Синдром емоційного вигорання у учителів $\epsilon$, по сугі процесом орієнтації особистості у інтраіндивідуальному просторі, що містить психокоституційні особливості і суб'єктивноособистісне ставлення до професійної діяльності, яке виявляється у порушенні аутоідентифікації особистості (когнітивному дисонансі). Центральним психологічним утворенням особистості, що забезпечує профілактику синдрому емоційного вигорання у педагогів $\epsilon$ формування компетентнісного підходу щодо поведінки у інтраіндивідуальному просторі, 3 формуванням когнітивного консонансу та можливості змінювати, удосконалюючи та розвиваючи свою особистість та професіоналізм.

\section{ЛІТЕРАТУРА}

1. Акиндинова И. А. Методы психологической помощи работе с последствиями синдрома эмоционального выгорания специалистов помогающих профессий. Психологический журнал. 2001. Т. 17. № 4. С. 56-72.

2. Бодров В.А. Информационный стресс: учебное пособие для вузов. Москва, 2000. 352 с.

3. Бойко В.В. Энергия эмоций в общении: взгляд на себя и на других. Москва, 2006. 472 с.

4. Булатевич Н.М. Синдром емоційного вигоряння вчителя : автореф. дис. канд. психол. наук: спец. 19.00.04 “Медична психологія". Київ, 2004. 19 с.

5. Водопьянова Н.Е., Старченкова Е.С. Синдром выгорания: диагностика и профилактика. Санкт Петербург, 2005. 336 с.

6. Кирхлер Э., Родлер К. Мотивация в организациях. Психология труда и организационная психология. Харьков. 2004. 168 с.
7. Китаев-Смык Л.А. Психология стресса. Москва, $1983.368 \mathrm{c}$.

8. Курлянд 3. Н. Педагогические способности и профессиональная устойчивость.Одесса, 1992. 122 с.

9. Микитюк О. М. Теоретико-методологічні засади формування соціо-екологічної компетентності учителів у системі післядипломної педагогічної освіти. Львів, $2013.368 \mathrm{c}$.

10. Микитюк О. М., Шиян О. І. Компетентнісний підхід до забезпечення здорового способу життя у сприятливому екосередовищі : [навч.-метод. посіб. для слухачів системи післядипломної педагогічної освіти]. (Гриф МОН№ 1.4/18-1845 від 25.05.2009 р.). Львів, 2009.36 с.

11. Митина Л. М., Асмаковец Е.С. Эмоциональная гибкость учителя: психологическое содержание, диагностика, коррекция. Москва, 2001. 190 с.

12. Maslach C. \& Golberg J. Prevention of burnout: New perspectives. Applied and preventive Psychology. 1998. Vol. 7.pp. 63-74.

13. Maslach C., 1978 (б). Job burnout: How people cope. Public Welfare. 36(2). pp. 56-58.

\section{REFERENCES}

1. Akindinkva, I. (2001). Metody psichologicheskoy pomochu rabote s posledstviamy cundroma emosialnogo vugorana spesialistow pomogayshich profesiy [Methods of psychological assistance to work with the effects of the burnout syndrome of specialists of helping professions]. Psychological Journal. Vol. 17. No.4, pp. 56-72. [in Ukrainian].

2. Bodrow V.A. (2000). Informasioniy stress [Informational stress: a textbook for universities]. Moskow, 352 p. [in Russian].

3. Boyko V.V. (2006). Energia emisiy i obchenia: vsglad na sebya $i$ na drygich [The energy of emotions in communication: a look at yourself and others ]. Moskow, 472 p. [ in Russian].

4. Bylatevich, H.M. (2004). Sundrom emosiynogo vigoranna [The syndrome of emotional burnout of a teacher]. Candidate's thesis. Kyiv, 19 p. [in Ukrainian].

5. Vodopjanowa, N. E. (2005). Sindrom vigarania; diagnostika i profilaktica [Burnout syndrome: diagnosis and prevention]. Saint Petersburg, 336 p. [in Russian].

6. Kirkchler, E. (2004). Motivasia w organizaciach. Psichologia truda i organizacionnaja psichologia [Motivation in organizations. Labor psychology and organizational psycholog]. Charkow, 168 p. [in Ukrainian].

7. Kitaew-Smuk, L.A. (1983). Psichologia stressa [Stress psychology]. Moscov, 368 p. [in Russian].

8. Kurland, Z. N. (1992). Pedagogicheskie sposobnosty i professionalnaja ustoychivost [Pedagogical abilities and professional stability]. Odesa, 122 p. [in Ukrainian].

9. Mykytyuk, O.M. (2013). Teoretyko-metodologichni sacady formyvanna cozsioecologichnoi competentnosti vchetuliw y sustemi pisladuplomnoi pedagpgichnoi osvity [Theoretical and methodological ambush formating social and ecological competences of teachers in systematic teaching and educational systems: [monograph]. Lviv, 368 p. [in Ukrainian].

10. Mykytyuk, O.M. (2009). Kompetentnisniy pidchid do zabezpechenna zdorowogo sposoby hutta y spriatluvomy ecoseredovuchi [Competent training for 